Maurer School of Law: Indiana University Digital Repository@Maurer Law

Articles by Maurer Faculty

Faculty Scholarship

1959

\title{
The Barenblatt Decision of the Supreme Court and the Academic Profession
}

Ralph F. Fuchs

Indiana University School of Law

Follow this and additional works at: http:/ /www.repository.law.indiana.edu/facpub

Part of the First Amendment Commons, Political History Commons, and the United States History Commons

\section{Recommended Citation}

Fuchs, Ralph F., "The Barenblatt Decision of the Supreme Court and the Academic Profession" (1959). Articles by Maurer Faculty. 2170.

http://www.repository.law.indiana.edu/facpub/2170 


\title{
The Barenblatt Decision of the Supreme Court and the Academic Profession
}

\author{
By RALPH F. FUCHS \\ Indiana University
}

A student or faculty member of a college or university, unless he invokes the privilege against self-incrimination, may be required by a legislative investigating committee to answer questions relating to his Communist Party membership and knowledge of Party activities, if the committee possesses previous indication of his possible membership. Such is the decision of the Supreme Court of the United States in the recent Barenblatt case, ${ }^{1}$ sustaining a conviction for contempt of Congress on account of Barenblatt's refusal on First Amendment grounds to answer certain questions of a subcommittee of the House Un-American Activities Committee in 1954.

Barenblatt was a graduate student and teaching fellow at the University of Michigan during the period 1947-50, to which the questions related, ${ }^{2}$ and the Committee, besides inquiring about Communist Party membership, asked Barenblatt whether he had been a member of the Haldane Club, an allegedly Communist Party offshoot in the University. Previous testimony before the subcommittee had named him as a member of the Party and of the Club.

The American Association of University Professors had filed a brief amicus curiae in the case, requesting the Court to decide that compulsion to answer the questions, under the circumstances of the case, was either unauthorized or unconstitutional. The Association's brief challenged the existence of authorization by the House of Representatives of the Un-American Activities Committee's investigation into education, as well as the Committee's authority to put the specific

1360 U. S. 109 (June 8, 1959).

Barenblatt was an instructor at Vassar College at the time he was summoned to appear before the subcommittee, but this fact was not significant in relation to the case, except as it linked his graduate training to membership in the academic profession. 
questions asked of Barenblatt. The Court sustained the Committee on both points. The brief further argued that such an investigation, if authorized by Congress without more justification than appeared in the case, would violate the First Amendment freedoms of speech and assembly, or association, in colleges and universities. This contention was based on the need for academic institutions to have independence from external pressures, the minor extent of the actual threat from Communism in higher education in this country, and the existing academic safeguards against improper activities in colleges and universities. Like the prior contentions, this one was unsuccessful.

It is important both to grasp the narrowness of the constitutional point actually decided by the Court and to gauge the possible significance of the decision on this point in relation to wider issues. The decision was by a 5-4 majority. The opinion of Mr. Justice Harlan for the Court and the dissenting opinion of $\mathrm{Mr}$. Justice Black articulate the philosophies underlying their opposite conclusions. Chief Justice Warren and Mr. Justice Douglas concurred in the Black opinion, and Mr. Justice Brennan, in a brief separate opinion, expressed his partial agreement with it and his support of the result it urged.

In justifying the Court's decision, the majority opinion relies heavily on prior judicial and legislative recognition of the purpose of the Communist Party to secure the ultimate overthrow of the government by force and violence. It recognizes the power of the legislature to enact laws to deal with this threat, and therefore to conduct inquiries relevant to such legislation. The case does not involve and the opinion does not pass upon the validity of criminal statutes or other governmental measures to combat subversive activities. ${ }^{3}$ The issue decided relates to the power of investigation to determine the need for legislation. The opinion points out that the investigation here was not of a "dragnet" variety, calling persons before the Committee indiscriminately as witnesses; and it is in light of this fact that the power to compel Barenblatt's testimony is sustained.

The dissenting opinion, as to the constitutional issue, rests primarily on the absolute terms of the First Amendment, which provides that "Congress shall make no law" abridging freedom of speech, press, or assembly. The opinion asserts that the inquiries of the Un-American Activities Committee, including this one, "do precisely that" by exposing witnesses to obloquy and public scorn, thus penalizing them for their exercising of freedoms supposedly protected by the First Amendment.

' Certain prior decisions dealing with particular problems in this area are reviewed in Carr's, "Academic Freedom, the American Association of University Professors, and the United States Supreme Court," Spring, 1959 AAUP Bulletin, at p. 5 . 
The opinion is an eloquent assertion of the importance of freedom of political discussion and association, and of the danger of permitting even small inroads into this freedom, because of the demonstrated likelihood of their expansion into major ones. The opinion protests against the Court's application of a balancing process-weighing national security claims against the claims of free speech and associationin order to determine the validity of an abridgement of expression and association. It asserts, however, that even if that method of reasoning is to be applied, the Court's use of it "completely leaves out the real interest in Barenblatt's silence, the interest of the people as a whole in being able to join organizations, advocate causes, and make political 'mistakes' without later being subjected to governmental penalties for having dared to think for themselves."

In justifying the balancing process for deciding the case, the majority opinion quotes a sentence from the Association's amicus brief, which recognizes that "the claims of academic freedom cannot be asserted unqualifiedly" and must be weighed against other social interests in determining the validity of governmental action affecting those claims. "Academic freedom" as used in the brief had reference to a complex of acts and relationships. The opinion points out that the inquiry in the Barenblatt case did not extend to the content of academic instruction, as did the questioning in the earlier Sweezy case. ${ }^{4}$ If it had, a decision that the inquiry was barred would almost certainly have resulted. The opinion recognizes the importance of academic freedom in the constitutional scheme in the following passage:

Of course, broadly viewed, inquiries cannot be made into the teaching that is pursued in any of our educational institutions. When academic teaching-freedom and its corollary learning-freedom, so essential to the well-being of the Nation, are claimed, this Court will always be on the alert against intrusion by Congress into this constitutionally protected domain. But this does not mean that the Congress is precluded from interrogating a witness merely because he is a teacher. An educational institution is not a constitutional sanctuary from inquiry into matters that may otherwise be within the constitutional legislative domain merely for the reason that inquiry is made of someone within its walls.

If First Amendment issues are to be decided by a process of balancing broad social interests, there is still both opportunity and need for definite propositions relating to the immunity of specific, narrowly defined freedoms from particular kinds of legislative invasion. The opinion of the Court, in the passage just quoted, enunciates such a proposition in relation to inquiries into the content of instruction.

4 In that case, the constitutional issue relating to the First Amendment was discussed but not decided. See the article by Carr, cited in the preceding footnote. 
Others might be stated, and may come to be adopted by the Court, with relation to constitutional protection of the individual from criminal punishment or legally imposed loss of employment on account of beliefs, utterances, or association involving the expression of views of any kind, including views which favor political revolution. Certainly within academic institutions and the academic profession, the absoluteness of freedom of belief, utterance, and association for the expression of belief must be unflinchingly maintained, and governmental efforts to invade it must be resisted.

The Court in the Barenblatt case, following previous official conclusions and prevailing opinion, accepts the view that the Communist Party's purposes, pursued secretly to some extent, include illegal action as distinguished from discussion, argument, and political action. Investigation into the extent of association with it can therefore be made, except where the individual interests at stake, or abuses in the investigative process such as the Court said were absent here, weigh more heavily in the balancing process than the governmental interest sought to be served. Here, the balance was struck in favor of the latter.

The determination of this last question is the principal inadequacy of the Barenblatt decision from the standpoint of the academic profession. The opinion does not deal expressly with the aspects of higher education to which the Association's brief pointed as factors needing to be estimated. "One of the essential preconditions of academic freedom," the brief asserted, "is unhampered control by the university over employment of its faculty," which should extend to the training of "candidates and novitiates," such as graduate students. The brief recited AAUP experience and developments set forth in recent literature, embracing denial or termination of academic employment as a result of the Barenblatt type of inquiry. ${ }^{5}$ It also pointed to the tendency of investigations such as those of the Un-American Activities Committee to lead students in particular "to prefer a posture of safety to the exercise of their freedoms." In the light of these factors, such investigations into Communism in higher education would better have been stopped by a constitutional barrier than allowed to continue, and the "academic autonomy," for which the brief argued, have been permitted free scope to supply needed safeguards against subversion in the colleges. At the very least, recognition might have been given to the need for considering the repressive effects upon higher education of inquiries such as that in this case, before coming to a decision.

- No assertion has been made that there was such a result in the Barenblatt case itself. 
In $N A A C P$ v. Alabama, ${ }^{6}$ decided a year earlier, the Court cast the balance in favor of organizational freedom against official scrutiny into membership, because of the adverse consequences which disclosure of the names of Negro members of a hated organization would have produced in Alabama. Although these consequences were more obvious and dramatic than the partial paralysis of independent thought and expression which now prevails in some academic circles, they were not more insidious or harmful.

It does not follow from the unconvincing nature of the reasoning of the majority of the Court that the dissenters who took an absolute position against any inquiry into "political" association are self-evidently correct. Wide-ranging legislative investigations have produced much good in this country, and restraints upon them must be kept to a minimum. It is certainly not clear that political association, carried on in secret, can be so definitely separated from indicated illegal activity of the same organizations as to permit immunizing it altogether from legislative investigations. The coercive effect upon individuals of Congressional investigations into Communism, which $\mathrm{Mr}$. Justice Black's opinion amply demonstrates, results from an inflamed state of public opinion as well as from the disclosures themselves. Although the investigations have been deliberately designed to stimulate this state of opinion and to produce maximum effect, counter-efforts in behalf of justice to individuals can be carried on in the area of public opinion, to which legislators are directly responsible. Hence the absence of a rigid rule against investigations of this type need not spell the end of basic constitutional freedoms.

In the counter-efforts that should be made, as well as in future constitutional litigation, other recent important judicial holdings can be put to use. These are to the effect that (1) legal action adverse to the individual cannot be based solely on past membership in the Communist Party, without reference to personal involvement in illegal activity $;^{7}$ (2) refusal to take a broad oath disclaiming membership, including innocent membership, in organizations which advocate overthrow of the government by force or illegal means cannot be in itself a ground of exclusion from office $;^{8}$ (3) a state investigation involving compulsory disclosure, which is likely to result in coercion against lawful association, is unconstitutional $;{ }^{9}$ and (4) the exercise of compulsion

- 357 U. S. 449 (1958).

7 Schreare v. State Board of Bar Examiners, 353 U. S. 232 (1957).

Wieman v. Updegraff, 344 U. S. 183 (1952); see also Speiser v. Randall, 357 U. S. 512 (1958).

- NAACP v. Alabama, 357 U. S. 449 (1958). 
field by a clear showing of relevance of the inquiry to a valid legislative purpose. ${ }^{10}$

Repressive measures of many varieties affecting academic freedom remain in effect on both the state and the national level. Many of these are far more serious than any Congressional investigations now being conducted. Among them are the various disclaimer oath laws, the laws which require faculty members to disclose their organizational affiliations as a condition of holding their official positions, and the laws which render it criminal to belong to organizations that "advocate" or even "believe in" the overthrow of the government by violence or illegal means. Not only are these measures ordinarily vague and uncertain in their operation, but they are symbolic of a wider legislative purpose to repress unorthodox views and associations, especially in the field of education. Efforts to combat these measures should be continued and intensified, lest the policy of enforcing conformity become permanent.

By and large, the academic profession can be far more vigorous in relation to these matters than in general it has been. The result in the Barenblatt case can be a call to more effective action, rather than a ground of discouragement. The current widespread effort to secure the repeal of the oath provision of the National Defense Education Act, with the discernibly favorable effect of that effort on public opinion, is a heartening indication of what can be done.

${ }^{10}$ Watkins v. United States, 354 U. S. 178 (1957) ; Sweezy v. New Hampshire, 354 U. S. 234 (1957). Uphaus v. Wyman, 360 U. S. 72, decided the same day as Barenblatt v. United States, does much to weaken the force of prior holdings on this point and the previous one, however, and goes far to justify the anticipation of Mr. Justice Black, in his dissenting opinion in Barenblatt, that the holding there could easily lead to widespread extensions. The compulsion to disclose in the Uphaus case, which the Court upheld, involved the names of numerous people whose possible connections with the Communist Party had not been indicated in a broad investigation of "subversion" embracing a variety of organizations and individuals. Mr. Justice Brennan's careful dissent in Uphaus reveals tellingly how far the majority of the Court actually went. The Court seems in reality to be developing in this area a familiar pattern of inconsistent lines of decisions, either of which can be drawn upon in the future. 